\title{
Кустарные промыслы как звено развития капитализма в деревне середины XIX - начала XX века: на материалах Семеновского и Макарьевского уездов Нижегородской губернии
}

\author{
Аксянов А.С. \\ Муниципальное автономное учреждение культуры архитектурно-этнографический музей- \\ заповедник «Щелоковский хутор», \\ Россия, 603081, г. Нижний Новгород, ул. Горбатовская, 41 \\ E-mail: aksyanov_aleksey@rambler.ru
}

\begin{abstract}
Аннотация. Статья посвящена анализу кустарных промыслов Семеновского и Макарьевского уездов Нижегородской губернии в середине XIX - начале XX столетия. Исследование акцентирует внимание на высоком социально-экономическом значении кустарной промышленности для местного населения. Опираясь на земские статистические данные и на периодическую печать, автор выделяет стержнеобразующие виды местной кустарной промышленности. Проведенный анализ позволяет определить факторы, повлиявшие на изменения кустарной промышленности севера Нижегородской губернии. В статье приводится классификация местных кустарей-производителей, основанная на их имущественном положении. Сделан вывод о переходном характере кустарных промыслов от простого товарного производства к крупному промышленному. Прогрессивное начало кустарной промышленности под воздействием объективных экономических процессов обернулось к началу XX века инструментом финансового закабаления мелких и средних кустарей.
\end{abstract}

Ключевые слова: кустарные промыслы, кустари, развитие капитализма, Нижегородская губерния, экономика Российской империи.

Для цитирования: Аксянов А.С. 2021. Кустарные промыслы как звено развития капитализма в деревне середины XIX - начала XX века: на материалах Семеновского и Макарьевского уездов Нижегородской губернии. Via in tempore. История Политология. 48(3): 661-669. DOI 10.52575/2687-0967-2021-48-3-661-669.

\section{Artisan production as a component of development of capitalism in rural areas in mid-19th - early-20th century, according to records of Semenov uyezd (district) and Makary uyezd (district) of Nizhny Novgorod gubernia (province)}

\author{
Alexey. S. Aksyanov \\ Municipal Autonomous Cultural Institution Open Air Museum of Architecture and Ethnography \\ «Schyolokovsky khutor», \\ 41 Gorbatovskaya St., Nizhny Novgorod, 603081, Russia, \\ E-mail: aksyanov_aleksey@rambler.ru
}

\begin{abstract}
The article is devoted to the analysis of artisan production of Semyonov district and Makary district of Nizhny Novgorod province in the mid- $19^{\text {th }}-$ early- $20^{\text {th }}$ century. The study focuses on the high socio-economic significance of the cottage industry for the local population. Scrutinizing the zemstvo statistics and local periodicals, the author identifies the core types of local artisan production. The factual
\end{abstract}


material selected by the author describes the development of the artisan production of the local region. The analysis allows to determine the factors that influenced the changes in the artisan production of the northern areas of the Nizhny Novgorod province. The article gives a classification of local artisans on the bases of their property status. The author comes to the conclusion that artisan production in rural areas had transition nature. Under the influence of objective economic processes, it transformed from an initially progressive phenomenon to an instrument of financial enslavement of small and medium producers by the turn of the $20^{\text {th }}$ century.

Keywords: Artisan production, artisans, development of capitalism, Nizhny Novgorod gubernia, handicraft, cottage industry, economy of Russian Empire.

For citation: Aksyanov A.S. Artisan production as a component of development of capitalism in rural areas in mid-19th - early-20th century, according to records of Semenov uyezd (district) and Makary uyezd (district) of Nizhny Novgorod gubernia (province). Via in tempore. History and political science. 48 (3): 661-669 (in Russian). DOI 10.52575/2687-0967-2021-48-3-661-669.

\section{Введение}

До первой половины ХХ столетия Россия - аграрная страна. Крестьянство - самая массовая категория населения дореволюционного периода истории страны. Созидательная деятельность крестьян была основой социально-экономического развития государства. Стяжая своим трудом экономическую основу страны и создавая возможность укреплять успехи в военном деле, культуре и образовании, крестьянское сословие оставалось при этом самым бесправным и ущемляемым. Крестьянин сеял хлеб, собирал урожай, занимался промыслом и торговлей, был солдатом. Крестьянин исполнял всевозможные повинности и платил подати в пользу своих господ и государства. В тоже время крестьянство не было однородным и имело множество противоречий внутри своего сословия.

\section{Объекты и методы исследования}

Объектом исследования данной статьи выступают кустарные промыслы Семеновского и Макарьевского уездов Нижегородской губернии в период с середины XIX - начала XX века. В ходе работы был использован анализ, синтез, метод дедукции и индукции. Примененный историко-типологический метод позволил определить категории кустарей и выделить факторы, повлиявшие на развитие кустарной промышленности региона.

\section{Результаты и их обсуждения}

I. Кустарные промыслы: социально-экономическое измерение. Крестьяне традиционно занимались земледельческим трудом. Распространенный образ «хлебопашца», живущего исключительно за счет земледелия, домашнего животноводства, не так однозначен. Крестьянство практиковало занятия торговлей, извозом, местными и отхожими промыслами. Некоторые крестьяне были способны «сколотить» внушительные капиталы. Одним из немаловажных элементов хозяйства крестьянина Нижегородского Заволжья были кустарные промыслы. Кустарная промышленность - простое, мелкотоварное, ориентируемое на рынок, чаще всего низкотехнологичное, часто с привлечением детского и женского труда производство. Здесь крестьяне выступали и как наемные рабочие мелкие, средние, иногда крупные собственники. Уровень развития кустарных промыслов демонстрирует всю сложность и переходный характер социально-экономических процессов включения крестьян в капиталистические отношения, протекающие в России на протяжении XIX - начале XX века.

Российское государство в той или иной форме всегда обладало значительными территориями, тем не менее «вопрос земли» стоял остро. Индустрия приходила в дореволюционную Россию медленно и тяжело. Земля была основой хозяйства вплоть до массо- 
вого внедрения машинного производства XX в. Основной формой сельского хозяйства в Нижегородском Заволжье было растениеводство. Особенно сложно было вести земледелие в лесистых, северных уездах Нижегородской губернии. Урожай крестьянина Семеновского и Макарьевского крестьянина был невелик и выражался в самый урожайный год в сам-5 (крайне редко), как правило, это сам-2, сам-3.

Ко второй половине XIX века крестьянам Центральной России земледелие дает дохода меньше, нежели посторонний заработок (кустарное производство или отхожий промысел). Очевидно, что в силу природно-географических причин крестьяне северных уездов Нижегородской губернии только земледелием прожить не могли. По расчетам исследователей конца XIX века, норма потребления хлеба крестьянина составляла 18 пудов ржи $(294,84$ кг) и 5 пудов $(81,9$ кг) других пищевых продуктов, получаемых в хозяйстве в год, не считая мяса, овощей, соли [Кустарные промыслы Нижегородской губернии..., 1894, с. 3]. Безусловно, данная норма потребления была идеальной и реальные цифры отличались в меньшую сторону. Крестьяне северных уездов Нижегородской губернии не могли вырастить себе необходимое количество хлеба, а в случае хорошего урожая хватало его до января-декабря, а иной раз до ноября [Приложение ко всеподданнейшему отчету..., 1891, с. 4]. Поэтому приходилось искать сторонний заработок в промыслах. Таким образом, специальные промысловые зоны выделяются в первую очередь из-за крайней малоземельности и неурожайности крестьянских наделов. «Малоземелье, являющееся следствием недостаточности надела или возрастания населения, естественное неплодородие почвы, не вознаграждающей в достаточной мере труд обработки, малая производительность крестьянского земледелия - результат низкой сельскохозяйственной техники и общих культурно-экономических условий, несоответствие платежей с доходностью земли - все это вызывает необходимость существования вне земледельческих заработков в крестьянском хозяйстве...» [Приложение ко всеподданнейшему отчету..., 1891, с. 11-12].

Как правило, по губернии кустарные промыслы занимали подчиненное положение земледелию. В то же время ряд отраслей производства вполне могли сочетаться с возделыванием земли. К примеру, валяльный и деревообрабатывающий промыслы менее всего отвлекают от земледелия мужчин. Часть весенне-летнего сезона крестьяне занимались вспашкой и засевом, а осенью-зимой - промыслами. Существовали территории, исключающие это правило: «...где население живет исключительно ручными производствами, мало и даже вовсе не обращаются к земледельческому труду... волости Хохломская, Чистопольская и Борская Семеновского уезда» [Приложение ко всеподданнейшему отчету..., 1899, с. 5]. Полностью отчуждали работников от земли промыслы, связанные с металлообработкой, например, кузнечное дело: «...Земледелие и промысел существуют вместе, служа подспорьем одно другом. Вообще для населения более важен промысел, чем земледелие...» [Карпов, 1880, с. 594].

Число крестьян, которые занимались исключительно земледелием, неуклонно уменьшалось. По расчетам статистов конца XIX в., прожиточный минимум крестьянской средней семьи в денежном выражении составлял 92,8 рубля в год [Васильев, 1985, с. 92]. Сумма покрывала часть пропитания, хозяйство и подати. Низкоплодородная почва севера нижегородской земли позволяла зарабатывать крестьянину 65,6 рублей. Таким образом, к промыслам крестьянству приходилось обращаться вынужденно, из-за жизненной необходимости. С доходов от промыслов крестьяне платили повинности, удовлетворяли различные потребности, в том числе недостаток в пище. Как справедливо замечают служащие нижегородского земства в конце XIX столетия: «Было бы глубокой ошибкой полагать, что крестьяне занимаются местными или отхожими промыслами ради одного того, чтобы заработать лишнюю копейку... Доходы, извлекаемые ими из посторонних земледелию заработков, не есть добавочные к тем средствам существования, которыя уже обеспечены земледелием - в длинной цепи крестьянского труда это необходимое звено, единственно дающее возможность свести в хозяйстве семьи концы с концами. И когда это звено выпада- 
ет, наступают все последствия крестьянского разорения...» [Кустарные промыслы Нижегородской губернии..., 1894, с. 1]. О распространенности и значимости кустарных промыслов на севере Нижегородской губернии говорит то обстоятельство, что Семеновский уезд по количеству кустарных промыслов занимал первое место среди уездов губернии. По переписке 1889 г., 17332 из 19852 дворов, 87,3\% занимаются промыслами. 94,1 \% мужчин заняты отхожим или местным промыслом [Материалы к оценке земель Нижегородской губернии..., 1893, с. 177]. Из отчета Министерства внутренних дел следует: «...с ранних пор промыслы, разного рода изделия и мелочная торговля составляют... по крайней мере главнейшее занятие крестьянина, чем и отличается Семеновский уезд от других уездов в губернии...» [Журнал Министерства Внутренних дел, 1856, с. 10].

II. Категории кустарей. По уровню вложений капитала в кустарное производство можно выделить несколько категорий промысловиков. К первой, самой массовой категории, стоит отнести промысловиков, занимающихся местным и отхожим промыслом с использованием материала заказчика, его помещения и на «казенных харчах» (бурлаки, строители, стиралы и каталы в валяльном промысле и т. д.). По существу, это наемные рабочие, ищущие сезонного или постоянного заработка. Их организация могла носить форму артели, которые, как правило, не были самостоятельны в хозяйственном отношении и нанимались к подрядчику.

Ко второй категории стоит отнести мелких самостоятельных товаропроизводителей, исполняющих несложные изделия или отдельные производственные операции. В данном случае не требовалось большого капитала. Данная категория работала у себя на дому с использованием собственных инструментов и пропитания. Наемных работников данная категория не имела. Трудились семьями. Сюда стоит отнести собирателей мха, вязальщиков варежек, чулок, лаптей, рыболовных сетей и т. д.). Здесь активно использовалась форма семейной кооперации. В производственном процессе участвовали женщины, дети и старики.

Третья условная группа представлена средним производителем. В данном случае требовался капитал для организации места работы, закупки сырья и инструмента, найма рабочих - проще говоря, необходимы были оборотные средства. Практиковалась семейная кооперация или привлекалось небольшое число наемных работников (валяльный промысел и прядение льна). Данная группа производителей могла исполнять полный производственный цикл либо отдельные операции. Как правило, представители данной группы обзаводились несколькими лавками с товаром для сбыта продукции на местных рынках и базарах. Нередко подобные производители нанимались на подряды к крупным капиталистам. К примеру, средний доход за год среднего производителя валенной продукции на конец XIX в. составлял около 184 рублей [Карпов, 1880, с. 608]. После разорения мелкие и средние шли в наем к крупным собственникам.

К крайней, четвертой категории стоит отнести крупных собственников, которые владели несколькими промышленными предприятиями в различных сферах (токарнями, мельницами, стирнями и т. д.), активно занимались торговлей, в том числе оптовой, имели интересы в области речных и железнодорожных перевозок товаров. Владели предприятиями по постройке крупных грузовых судов, заготовке дровяного и строевого леса. Оборотные капиталы данных кустарей могли доходить до сотен тысяч рублей и выше. Активно использовали наемный труд.

III. Кустарные промыслы: факторы развития. Традиционно в северных уездах Нижегородской губернии практиковалось несколько стержнеобразующих видов кустарной промышленности: «В Семеновском уезде казенных удельных и владельческих крестьян 27 371, женщин 33599 душ... Крестьяне сего уезда занимаются... деланием из шерсти сапог, простых шляп, валенок, войлоков, приготовлением деревянной посуды, тканьем рогож и кузнечной работой» [Духовский, 1827, с. 67-68]. Сохранились данные по количеству крестьян, вовлеченных в каждую отрасль: в деревообработку (9 149 кустарей), пере- 
работку шерсти (5 340 ремесленников), металлообработку (3 376 человек) [Васильев, 1985, с. 98]. Можно говорить о том, что переработка древесины, шерсти и металла являлась одной из экономических основ севера Нижегородской губернии. Основная часть производимых товаров кустарной промышленности севера Нижегородской губернии были предметы быта для городских низов и крестьян. В основном это одежда и обувь, посуда и кухонная утварь, простая мебель, средства передвижения и т. д. Со временем данные векторы промышленного хозяйства претерпевали изменения, расцветали и гасли, в зависимости от экономической конъектуры. Кустарная промышленность не была статичной. На ее изменения воздействовали различные факторы.

Принципиальное значение для заволжского крестьянина-кустаря имел лес. Точнее, доступность сырья - древесины. К концу XIX столетия доступность древесного материала сильно упала. Рыночные принципы ведения лесного хозяйства не могли не отразиться на кустарном производстве. Торги по казенным делянкам стали просто недоступны мелким и средним кустарям. Цена леса сильно возросла. Вся вертикаль производственных процессов реагировала на эти процессы: «...12 марта состоялись в Богоявленском волостном правлении торги на продажу казенного леса из бараниховского лесничества в Богоявленской даче для заготовки кустарям ложкарного материала. Назначенные в продажу лесные делянки все раскуплены... и целиком попали в руки богатых скупщиков, от которых бедняки и получают весь материал; ложкарю приходится оплатить сверх высокой цены материал, еще и барыш скупщика. А ложки в цене понизились...» [Нижегородская земская газета № 17, 1904, с. 423]. Лишение крестьян-кустарей доступа к сырью определяло дальнейшее развитие деревообрабатывающего промысла на севере губернии, поскольку «...Доходность семеновских кустарных промыслов держалась на общедоступности и дешевизне первоначального материала...» [Материалы к оценке земель Нижегородской губернии..., 1893, с. 179]. Лес крестьяне вынуждены были покупать. Появилась потребность в небольшом оборотном капитале для приобретения березняка, осины, дров на уголь, смолы и прочее. Изделие оставалось в прежней цене либо «падало» в ней, поскольку цена устанавливалась перекупщиком. Поэтому крестьянам приходилось по-своему реагировать на изменения. Кустари переходили на сорт древесины хуже или с производства посуды и кадок переходили на «резание» ложки. Качество дерева приходилось компенсировать долгой выделкой плохого материала, что удлиняло производственный процесс. Цену изделия компенсировали количеством изготовленного товара. Удорожание сырья крайне негативно сказалось на материальном состоянии мелких и средних производителей [Приложение ко всеподданнейшему отчету о состоянии Нижегородской губернии ..., 1887 , c. 8].

Отразилось на некоторых кустарных промыслах введение машинного хозяйства. К примеру, «пострадал» гвоздарный промысел Красной Рамени Семеновского уезда. Отсутствие заработка заставляло бросать крестьян это занятие и обращаться к более выгодным, как правило, отхожим. Кустарь мог зарабатывать на производстве гвоздей 1 рубль 50 копеек в неделю. Металлообработка сильно зависит от угля, а в этой отрасли также обнаруживал себя кризис: «Значительно пало и гвоздарное производство... вследствие вздорожания угля, частию введения машинного гвоздарного производства...» [Приложение ко всеподданнейшему отчету о состоянии Нижегородской губернии..., 1882, с. 9]. Ко второй половине XIX века местные мастера полностью перешли на уральское железо в связи с его дешевизной в сравнении с выработкой местного. Также пострадало производство берд в связи с распространением машинного ткачества.

Ключевым фактором, воздействующим на кустарные промыслы, было доминирование крупного капитала над мелким и средним производителем-кустарем. Выкуп леса для последующей его перепродажи был не единственным способом влияния на кустаря. Существовали формы прямого финансового давления на мелких производителей и наемных рабочих. Практиковалось следующее: скупщик расплачивается за работу с кустарем- 
производителем натуральным товаром, цену на который устанавливает заведомо выше рыночной. К примеру, на ржаную муку скупщик ставит цену в 1 рубль за пуд, в то время как на рынке она стоит 80 копеек; пшеница - 2 рубля 50 копеек, на рынке - 1 рубль 50 копеек; 1 фунт сахара - 20 копеек, на рынке - 16 копеек и т. д. [Нижегородская земская газета № 1, 1904, с. 22]. В то же время цену на товар скупщик сознательно занижал. Подобным образом скупщик оборачивал свой капитал несколько раз в год, что давало ему немыслимый процент. Подобные примеры встречаются повсеместно во всех отраслях. В Красной Рамени на производстве цепей, гвоздей и весовых коромысел: «...В нынешнем году цепной работы так же с излишком... заработанных денег с наших хозяев не проси... Денег не платят, а заставляют за работу получать разным хозяйственным припасом, а именно: для работы углем, ... мукой, пшеном, чаем, сахаром, мылом... против базарных цен отпускают все припасы по дорогим ценам...» [Нижегородская земская газета № 28, 1904, с. 738]. Мелкий кустарьпроизводитель, попадая в кабалу к такому скупщику, не мог выбраться из этого круга, поскольку существовал риск полностью лишиться хоть какого-либо заработка: «...скупщики крашенный везде продают... Вся торговля нашим изделием переходит в более богатые руки, которые могут выдержать товар до настоящего времени и цены. . скупщики вступают в стачку... они объявили: "нам товару не надо, потому что война“, а нам деть некуда товар, и так уронили цены...» [Нижегородская земская газета № 28, 1904, с. 150]. Таким образом, контроль за промыслом переходит к нескольким скупщикам монополистам, «...эксплуатирующих их [кустарей, добавлено А.С.] труд» [Приложение ко всеподданнейшему отчету о состоянии Нижегородской губернии..., 1889, с. 6].

Нередки были сговоры крупных собственников о цене на товар: «...покупателикулаки понизили плату на 1 руб. 50 коп. за тысячу [ложек] по уговору между собой по случаю железнодорожных в России забастовок...» [Жизнь в губернии. Нижегородская земская газета № 49, 1905, с. 1302]. Кустарю создавались условия, при которых он попадал в безысходное положение и шел работать на «хозяина» на его условиях: «...Рабочий при поступлении к хозяину станет договариваться, чтобы хозяин ему за работу платил деньгами, а не припасами, то хозяин такого смельчака не принимает...» [Нижегородская земская газета № 28, 1904, с. 739-740].

Условия жизни мелкого кустаря заставляли его сознательно «залезать» в долги. В источниках встречаются схемы, при которых крестьянин мог лишиться своего собственного земельного надела: «...повысился \% безлошадных крестьян, \% безземельных; усиленней потянулось население к отхожим промыслам; разрослась сдача земли в аренду, продажа ее... Кустарь стал мало-помалу нищать. У него открылись долги земству за «ссуды», недоимки за «сборы» - недоимки правительству, долги частным лицам и хозяину... Кустарь решался на самый отчаянный шаг, чтобы спастись от нищеты и босячества - стал закладывать землю хозяину в обеспечении своей кредитоспособности. Этот заклад производится путем особых дутых сделок и расписок. За январь и февраль месяц прошлого года в с. Елховка, кажется, не было дня, чтобы при сельском правлении не было написано 4-6 «расписок-условий» о закладе земли... Гвоздарь просит у хозяина «трешницу»... - Да ты мне уже должен двадцать два рубля! - ворчит на него хозяин. Тогда гвоздарь предлагает ему записать за ним 25 рублей (22 р. старых и плюс 3 р. новых). Вот тут-то и пишется фиктивная расписка такого содержания: «Я, нижеподписавшийся крестьянин $\mathrm{N}$ с. Елховка, отдаю в арендное пользование на пять лет всю свою землю в количестве одной души (3 д.) крестьянину L-ву (то есть хозяину) с условием оплаты мне за аренду по 5 рублей в год. Деньги получены мною сполна»... кустарь совсем и не думал отдавать ему в аренду свою землю и денег с него не получал, а свой долг обязался выплатить ему в 5 лет, по 5 рублей в год. Если, положим, гвоздарь не уплатит первых пяти рублей за первый год, то хозяин на основании такой расписки прогонит его с земли и возьмет ее себе в качестве арендованной... И вот эта расписка-то заставляет теперь кустаря работать, во-первых, на хозяина гвозди (чтобы уплатить ему 25 р.) и пахать землю, чтобы не голодовать и не си- 
деть в арестантской за недоимки, и чтобы земля не попала в руки ловкого хозяина. Таким образом, гвоздарь закрепощает себя на долгие годы... » [Закрепощение кустаря. Нижегородская земская газета № 3, 1905, с. 66-67].

Одним из факторов, тормозивших развития кустарной промышленности, были низкие условия труда. Продолжительность рабочего дня, безопасность рабочего места, общие условия, в которых работал кустарь, были далеки от современных стандартов. В валяльном промысле встречались работники, которые трудились только на себя, но с дальнейшим распространением разделения труда и товарно-денежных отношений все больше распространялся наемный труд. Средний наемный мастер работал в день около 16 часов. В небольших мастерских «хозяин» брал себе самую простую работу, а на самые трудные операции, такие, например, как битье шерсти и стирку, нанимал рабочих: «...труд здешнего крестьянина гораздо тяжелее труда фабричного, и здешний крестьянин живет в постоянном страхе, что завтра или послезавтра, с его болезнью или смертью, окажется в нищете его семья... они [кустари, добавлено А.С.] из года в год живут без денег, запутанные долгами в руках кулаков...» [Смолокуры. Нижегородская земская газета № 9, 1905, c. 221].

Тяжело было положение кустарей, трудившихся в лесах по добыче строевого леса, скипидара, смолы и древесного угля. «...Ветлужский смолокур? Это существо, живущее в полной «кабале» у хозяина, правило которого: "что хочу, то и делаю“... его рабочий день тянется... чуть ли не 24 часа, т. е. полные сутки!..» [Смолокуры. Нижегородская земская газета № 7, 1905, с. 174-176]. Доходы смолокуров в сравнении с трудозатратами также невелики: «...кустарь-смолокур, который недоедал и не досыпал целых 7 месяцев, остается с жалкими 100-200 руб. в кармане, а чаще всего «в кабале» у перваго!..» [Смолокуры. Нижегородская земская газета № 9, 1905, с. 221].

\section{Заключение}

На территориях Семеновского и Макарьевского уездов с середины XIX - начала $\mathrm{XX}$ столетия активно развиваются товарно-денежные отношения и распространяются капиталистические принципы ведения хозяйства. Крестьяне-кустари включаются в общественное разделение труда. Проявляется экономическая дифференциация в среде кустарей. Имущественное расслоение к концу XIX - началу XX столетия приводит к выделению нескольких категорий кустарей-промысловиков: беднейших слоев, лишенных всех средств производства и работающих как наемные рабочие или в качестве отхожих промысловиков; мелких и средних производителей, работающих на крупного заказчика; зажиточных «хозяев», владеющих большим капиталом, кустарями которых назвать уже сложно.

К наиболее незащищенным категориям местных кустарей можно отнести наемных работников и мелких производителей. Данные категории характеризуются зависимостью от крупного капитала и конъектуры рынка; работой в тяжелых условиях труда; высокими рисками, связанными с болезнями, травмами и смертью кормильца; вынужденностью привлечения к работе детей; нахождением в постоянном состоянии задолженности; отсутствием возможности улучшения своего материального состояния.

К существенным факторам, определяющим переходный характер кустарных промыслов, стоит отнести лишение мелких и средних крестьян-кустарей легкого доступа к дешевому сырью для производства; внедрение машинного производства в ряд отраслей кустарной промышленности; финансовую зависимость беднейших, мелких и средних кустарей от крупного капитала; тяжелые условия труда кустаря.

Имея прогрессивное начало, в конце XVIII - начале XIX столетия кустарная промышленность способствовала выживанию крестьян в северных уездах Нижегородской губернии. Более того, являясь весомым подспорьем к хозяйству, позволяла стабилизиро- 
вать финансовое состояние местного крестьянства. С развитием товарно-денежных отношений и капиталистических принципов хозяйствования кустарная промышленность становится инструментом закабаления беднейших крестьян, мелких и средних производителей. Кризисные явления в кустарной промышленности способствовали пролетаризации крестьян, укрупнению отдельных отраслей производства и капитала. Можно говорить о развитии кустарных промыслов как о переходном моменте от простого товарного производства к крупному промышленному, как о звене развития капитализма в Российской империи.

\section{Список литературы}

1. Васильев Ф.В. 1985. Материальная культура крестьян нижегородского Заволжья во второй половине XIX - начале XX в. (хозяйство, поселения, усадьба). Дис. ... канд. ист. наук. Горький, 98.

2. Духовский М. 1827. Статистическое описание Нижегородской губернии, составленное тамошней гимназии старшим учителем Михаилом Духовским. Казань, Печатано в Университетской типографии, 67-68.

3. Жизнь в губернии. Нижегородская земская газета № 49, 1905 г. 1302.

4. Журнал Министерства Внутренних дел. 1856 г. Часть 16. С.-Пб., 10.

5. Закрепощение кустаря. Нижегородская земская газета № 3, 1905 г. 66-67.

6. Карпов А. Валеный и щепной промыслы в Семеновском и Балахнинском уездах. / Труды комиссии по исследованию кустарной промышленности в России. Выпуск 6. С.-Пб. 1880., 608.

7. Кустарные промыслы Нижегородской губернии. Издание Нижегородского губернского земства. Сост. М.А. Плотников. Нижний Новгород. 1894 г., 3.

8. Материалы к оценке земель Нижегородской губернии. Экономическая часть. Выпуск XI. Семеновский уезд. Н. Новгород. 1893 г., 177.

9. Нижегородская земская газета № 1, 1904 г., 22.

10. Нижегородская земская газета № 17, 1904 г., 423.

11. Нижегородская земская газета № 28, 1904 г., 738.

12. Нижегородская земская газета № 7, 1904 г., 150.

13. Приложение ко всеподданнейшему отчету о состоянии Нижегородской губернии за 1881 год. Н. Новгород, тип. Губернского правления, 1882.

14. Приложение ко всеподданнейшему отчету о состоянии Нижегородской губернии за 1888 год. Н. Новгород, тип. Губернского правления, 1889.

15. Приложение ко всеподданнейшему отчету о состоянии Нижегородской губернии за 1890 год. Н. Новгород, тип. Губернского правления, 1891.

16. Приложение ко всеподданнейшему отчету о состоянии Нижегородской губернии за 1898 год. Н. Новгород, тип. Губернского правления, 1899.

17. Смолокуры. Нижегородская земская газета № 7, 1905 г., 174-176.

18. Смолокуры. Нижегородская земская газета № 9, 1905 г., 221.

\section{Reference}

1. Vasil'ev F.V. 1985. Material'naya kul'tura krest'yan nizhegorodskogo Zavolzh'ya vo vtoroy polovine XIX - nachale XX v. [Material culture of the peasants of the Nizhny Novgorod Trans-Volga region in the second half of the XIX - early XX century] (khozyaystvo, poseleniya, usad'ba). Dis. ... kand. ist. nauk. Gor'kiy, 98.

2. Dukhovskiy M. 1827. Statisticheskoe opisanie Nizhegorodskoy gubernii, sostavlennoe tamoshney gimnazii starshim uchitelem Mikhailom Dukhovskim [Statistical description of the Nizhny Novgorod province, compiled by the local gymnasium senior teacher Mikhail Dukhovsky]. Kazan', Pechatano v Universitetskoy tipografii, 67-68.

3. Zhizn' v gubernii. Nizhegorodskaya zemskaya gazeta № 49 [Life in the province. Nizhny Novgorod zemskaya gazeta No. 49], 1905 g. 1302.

4. Zhurnal Ministerstva Vnutrennikh del. 1856 g. Chast' 16 [Journal of the Ministry of Internal Affairs. 1856 part 16]. S.-Pb., 10. 
5. Zakreposhchenie kustarya. Nizhegorodskaya zemskaya gazeta № 3 [Enslavement of the artisan. Nizhny Novgorod zemskaya gazeta No. 3] 1905 g., 66-67.

6. Karpov A. Valenyy i shchepnoy promysly v Semenovskom i Balakhninskom uezdakh / Trudy komissii po issledovaniyu kustarnoy promyshlennosti v Rossii. Vypusk 6 [Valenyy and shchepnoy crafts in Semyonovsky and Balakhninsky district / Proceedings of the Commission for the Study of the handicraft industry in Russia. Issue 6]. S.-Pb. 1880., 608.

7. Kustarnye promysly Nizhegorodskoy gubernii. Izdanie Nizhegorodskogo gubernskogo zemstva [Handicrafts of the Nizhny Novgorod province]. Sost. M.A. Plotnikov. Nizhniy Novgorod. 1894 g., 3.

8. Materialy k otsenke zemel' Nizhegorodskoy gubernii. Ekonomicheskaya chast'. Vypusk XI. Semenovskiy uezd [Materials for the assessment of the lands of the Nizhny Novgorod province. The economic part. Issue XI. Semenovsky district]. N. Novgorod. 1893 g., 177.

9. Nizhegorodskaya zemskaya gazeta № 1 [Nizhny Novgorod Zemskaya gazeta No. 1], 1904 g., 22.

10. Nizhegorodskaya zemskaya gazeta № 17 [Nizhny Novgorod Zemskaya gazeta No. 17], 1904 g., 423.

11. Nizhegorodskaya zemskaya gazeta № 28 [Nizhny Novgorod Zemskaya gazeta No. 28], 1904 g., 738.

12. Nizhegorodskaya zemskaya gazeta № 7 [Nizhny Novgorod Zemskaya gazeta No.7], 1904 g., 150.

13. Prilozhenie ko vsepoddanneyshemu otchetu o sostoyanii Nizhegorodskoy gubernii za 1881 god [Appendix to the most comprehensive report on the state of the Nizhny Novgorod province for 1881]. N. Novgorod, tip. Gubernskogo pravleniya, 1882.

14. Prilozhenie ko vsepoddanneyshemu otchetu o sostoyanii Nizhegorodskoy gubernii za 1888 god [Appendix to the most comprehensive report on the state of the Nizhny Novgorod province for 1888]. N. Novgorod, tip. Gubernskogo pravleniya, 1889.

15. Prilozhenie ko vsepoddanneyshemu otchetu o sostoyanii Nizhegorodskoy gubernii za $1890 \operatorname{god}$ [Appendix to the most comprehensive report on the state of the Nizhny Novgorod province for 1890]. N. Novgorod, tip. Gubernskogo pravleniya, 1891.

16. Prilozhenie ko vsepoddanneyshemu otchetu o sostoyanii Nizhegorodskoy gubernii za 1898 god [Appendix to the most comprehensive report on the state of the Nizhny Novgorod province for 1898]. N. Novgorod, tip. Gubernskogo pravleniya, 1899.

17. Smolokury. Nizhegorodskaya zemskaya gazeta [Smolokury. Nizhny Novgorod Zemskaya gazeta] № 7, 1905 g., 174-176.

18. Smolokury. Nizhegorodskaya zemskaya gazeta [Smolokury. Nizhny Novgorod Zemskaya gazeta] № 9, 1905 g., 221.

Конфликт интересов: о потенциальном конфликте интересов не сообщалось.

Conflict of interest: no potential conflict of interest related to this article was reported.

\section{ИНФОРМАЦИЯ ОБ АВТОРЕ}

Аксянов Алексей Сафович, хранитель фондов муниципального автономного учреждения культуры архитектурно-этнографического музея-заповедника «Щелоковский хутор», Нижний Новгород, Россия

\section{INFORMATION ABOUT THE AUTHOR}

Alexey. S. Aksyanov, the curator of Municipal Autonomous Cultural Institution Open Air Museum of Architecture and Ethnography «Schyolokovsky khutor», Nizhny Novgorod, Russian. 